I. Official Punlinations Issued by the Government Printing office. (Listeó in Cihronsivical Order.)

These papers may be consulted at any Government Depository Library, of which there is at least one in eech congressional district. A complete list of these libraries is contained in Bureau of Stardards Gifcular No. 24, obtairable from the PubIication Sectiun, Eurcau of Standaras, Washington, D. C.

Provided they are not out of print, these papers may be purchased of the Superintendent of Dccuments, Government Printing Office, Washington, D. C., at the prices listed. If the price is enclosed in parentheses, the paper is out of print and not available.

The significance of the letters preceding publication numbers is as follows:-

$S$ means "Scientific Paper of the Bureau of Standards".

T means "Tecinnologic Purer of the Bureau of Standards".

C means "Circular of the Bureau of Standards".

M means "Miscellaneous Publication of the Bureau of Standards".

An asterisk (*) before the title indicates that the major responsibility for the paper lies with sone section of the Bureau other than the Colorimetry Section, but that the latter section has afforded considerable advice or assistance in the mork.

Two asterisks $(* *)$ before the title indicates that the paper emanates from some section of the Surency other than the colorimetry section, but has a bearing on colorinetry or close relation to it. However, numerous parers vish might be so classed (on spectroradiometry, photomet For complete list, consult B. S. Circular No. 24 , and supplements to it.

Three asterisks $(* * *)$ before the title indicates that the paper antedates the formal organization of the Colorimetry seetion at the Bureau. 
Date of Paper Price issue No.

TALBOT:S TAT AS APPIIED TO THE ROTATING SEICTCRYD DISIS Edward P. Hyde

*** A POCKET SPECTROPHOTOMETER

P. G. Nutting

*** COMPLETE FORM OF FECHNER'S LAW P. G. Nutting

*** PURITY AND INTENSITY OF MONCCHROMA'I IC IIGHT SOUROES

P. G. Nutting

*** THE LUMINOUS EQUIVALENT OF RADIATION

P. G. Nutting

*** A METHOD FOR CONSTRUCTING THE NATURAI SCALE OF PURE COLOR

P. G. Nutting

*** THE DAYLIGHT EFFICIENCY OF ARTIFICIAL ILLUMINANTS

Herbert $\mathrm{E}$. Ives

*** LUMINOSITY AND TEMPERATURE

P. G. Nutting

*** WHITE LIGHT FROM THE MERCURY ARC

AND ITS COMPLEMENT ARY

Herbert $E$. Ives

*** THE VISIBILITY OF RADIATION. A RECALCULATION OF KONIG'S DATA

P. G. Nutting

*** A PHOTOMETRIC ATTACHMENT FOR SPECTROSCOPES

P. G. Nutting

*** THE DETERMINATION OF THE OPTICAL PROPERTIES OF MATERIALS

*** A NEW PRECISION COLORIMETER

P. G. Nutting
March 1, S $26 \quad 15 \phi$ 1906

July 15, S 39 1906

Dec. 25, S 49 1906

Sept. I, S 44 1907

Sept. 3, S 103 1908

Apr. 27, S 118 1909

May, 1909

S 125

$\begin{array}{cc}\text { July, } & \text { S } 133\end{array}$

Avg. 1, S 128 1909

oct. 1, S 154 1910

Oct. 1 ,

S 155 1910

March 1 C 28 1911

July 25, S 187 1912 


Issie

SPECIFICATION OF THE TRANEPSRENCY OF PAPER AND TRACIIG CIOTH

* AN "AVERAGE EYE" FCR HET EROCHROMATTC PHCDOMETAY, ADI) OCHEATISON OF A FLICTER AID AN EQUALIYY-OF-BRTGHTNESS PHOTOMETER

E. C. Crittenden and F.K. Richtmyer

** LUMINOUTS RADIATION FROM A BLACK BODY AND THE MECHANIOAL EQUIVALENT OF LIGHT w. Wublentz and W. B. Enerson

MEASUREMENT AND SPECIFICATION OF THE PHYSICAL FACTORS WIICH DETEFUINE THE SATURATION OF CERIAIN TINTS OF YELLON

Irwin G. Priest and Chauncey G.Feters

** RELATIVE SENSIBILITY OF THE AVERAGE EYE TO LIGHT OF DIFFERENT COLORS AINT SOIE PRACTICAL APPLICATIONS TO RADIATION PROBLIMS

W. W. Coblent: and $\mathbb{W}$. B. Emerson

** SPECTRORADIOMETRIC INVESTIGATION OF THE TRANSMISSION OF VARIOUS SUBSTANCAS W. W. Coblentz, W. B. Emerson, anc M. B. Long

** GLASSES FOR PROTECTING THE EYES FROM INJURIOUS RADIATIONS

W. W. Coblentz and W. B. Emerson.

THE ULTRA-VIOLET AND VISIBLE TRANSMISSION OF EYE-PROTECTIVE GLASSES

K. S. Gibson and H. J. MCNicholas

PHOTO-EIECTRIC SPECTROPHOTOMETRY BY THE NULL VITHOD

K. S. Gibson

CONTRAST SENSIBILITY OF THE EYE

Enoch Karrer and E.P.T: Tydall
May 17, C $635 \not$ 1917

May $26, \quad s 299 \quad \varepsilon \not$ 1917

June 30, S $305 \quad 5 \phi$ 1917

June $30, T$ T 56 1917

Sept.12, s $303 \quad 15 \phi$ 1917

Aug. 8, S $325 \quad 5 \not$ 1.918

Feb.28, T $93 \quad 10 \not$ 1.319 (oraidr.)

June 7, T 119 10ф 1919

oct. 11, S 349 5ф 1919

March 8, s $3665 \notin$ 1900 
$\because$ 
Title and Author

Date of Paper Prioe Issue No.

THE ULTRA-VICLEM AND VISTEZE TRANSMISSION OF VARIOUS COLORED GLASSES

K. S. Gibson, E.P.T.Tyndall, and

H. J. MoNicholas

RELATIVE SPECTRAL TRANSMISSION OF THE ATMOSPHERE Enoch Karrer and E.P.T.Tyrdall

Woh. 19, T $148 \cdot 10 \notin$ 1920

July 21, S 389 10ф 1920

* MEASIJREREIT OF DIEFUSE REFLECTION HACTORS, AND A NEW ABSOLUTE REFLECTONETR

A. H. Taylor

COLOR AND SPECTRAL COMPOSITION OF CER-

TAIN HIGH-INTEITSITY SEARCHLIGHT ARCS

Irwin G. Priest, . T. Meggers,

K. S. Gibson, E.F.T.TyndaII, and

H. J. McNicholas

AN EXAMINATION OF THE MUNSELI COLOR SYSTEM I. SPECTRAL AND TOTAL REFLECTION AND Sept.30, T 167 106 THE MUNSELI SCALE OF VALUE

Irwin G. Priest, K. S. Gibson, and

H. J. MeNicholas

** A SIMPLE FORTABLI INSTRUMENT FOR THE ABSOLUTE MEASUREMENT OF REFLECTION AND TRANSMISSION FACTORS

A. H. Tayior

** USE OF THE ULBRICHT SFHERE IN MEASURING REFLECTION AND TRANSMISSION FACTORS Enoch Karrer

THE SPECTRAL DISTRIBUTION OF ENERGY REQUIRED TO EVOKE THE GRAY SENSATION

$$
\text { Irwin } G \text {. Friest }
$$

** SPECTRORADIOMETRIC INVEST IGATION OF THE TRANSMISSION OF VARIOUS SUBSTANCES, II

iv. Coblentz

Nov.30, S $405 \quad 5 \phi$ 1.920

Aug.10, S 415 5ф 1921

Aug. 25, S $417 \quad 10 \notin$ 1921

Aug.29, S $418 \quad 5 \not$ 1921

Aug.12, T $168 \quad 5 \phi$ 1920 1920

S 391 

Date of Taper Frice Issue No.

THE SPECTRAT TRANSMISSIVE FROE TRTIES OF

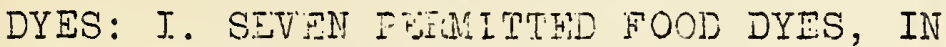
June $15, S 44015 \phi$ THE VISTBT,E, ULTRA-VIOLIT, AND NEAR

INFRA-RET

K.S. Gibson, H. J. MeNicholas, E.F.T. Tyndal1, and M. K. Frehafer, with the cooperation of W. E. Mathewson, Bureau of Chemistry

MEASUREMENT OF THE COIOR TEMFERATURE OF THE MORE EFFICIEIT ARIIFTCIAI LIGHI SOURCES BY THE METHOD OF ROTATORY DISPERSION Irmin G. Friest

VISIBILITY OF RADIANT ENERGY

K. S. Gibson and E.F.T.TyndaII

OF WHITE PAPER

R. E. Lof ton

**PULF AND FAFER FIBER COMFOSITION STANDARDS: REF ERENCE STANDARDS, SHOWING THE COLOR REACTIONS OF COMMON FAFER -MAXING FIBERS AND STANDARD FIBER MIYTURES WITH VARIOUS STAINS FOR USE IN IDENTTFICATION AND ESTIMATION OF FIBER CORFOSITION OF FAFER

Muriel F. Merritt

TABLES AND GRAFHS FOR FACILITATING THE COMPUTATION OF SPECTRAL EIEEIGY DISTRIBUTION BY FLANCK'S FORHULA

M. Katherine Frehafer and Chester L. Snorr

RILOCYCLE-METER CONTERSION TABIE. (While designed particularly for use in radio work, this table will be found equally useful in the visible range of radiation: $3 . g .$, if used intelligently with proper placing of the decimal point, it may serve to convert wave lengths in millimicrons to frequency in trillions per second (fresnels).)

Aug.11, S $475 \quad 15 \notin$ 1923

Nov.17, T $2445 \notin$ 1923

July $24, S 4435 \notin$ 1922

Apr.25, T 250 15k 1924

Mch.21, M 56 35ф 1925

Oct.9, 1925
M 675 6 
$4 \quad$ 
Papersoncolorimetry

\section{Title and Author}

Date of Paper Price Issue

* A PHOTOMETRIC METHOd for MEASURING THE HIDING POWER

OF PAINTS

H. D. Bruce

THE IOVIBOND COIOR SYSTEM, I. A SPECTROPHOTOMETRIC AN-

AIYSIS OF THE IOVIBOND GIASSES

K. S. Gibs on and F. K. Harr is

Jan.z6, T $306 \quad 10 \varnothing$

1926

(B. S: Sci. Paper in press. Will probably be issued about Jenuary, 1927.) 

II. Papers Jinanatine from the Colorimetry section, Bureau of Standards. Friblisted Es serhne than in the Official Publications of the Bureau. (iisted in Chronologic Order.)

An asterisk $(*)$ before the title indicates that the author was not a regular member of the Cclorimetry Section, but that he used its laboratory facilities or obtained considerable advice or assistance from the section in carrying on the mork reported in the paper.

An asterisk (*) after the title indicates an abstract of $a$ paper presented before some scientific society, containing usually information not published olserwere.

To asterisks (**) after the title indicates a committee roport in the preparation of which some member or mombers of the section cooperated.

1. COLOR SPECIFICATIONS* Irmin G. Priest

2. THE QUARTZ COLORIMETER AND ITS APPLICABILITY TO THE COLOR GRADING OF COTTON SEED OIL. Irwin G. Priest

3. REPORT ON INVESTIGATIONS CONCERN ING THE COLOR AND SPECTRAL TRANSMISSION OF COTTON SEED OIL*

Irmin G. Priest and Chauncey

G. Peters

4. THE BUREAU OF STANDARDS CONTRAST METHOD FOR MEASURING TRANSPARIINCY. Irmin G. Priest

5. A PROPOSED METHOD FOR THE PHOTOMETRY OF LIGHTS OF DIFFERENT COLORS*. Irmin G. Priest

6. THE WORK OF THE NATIONAL BUREAU OF STANDARDS ON THE ESTABLISHMENT OF COLOR STANDARDS AND METHODS OF COLOR SPECIFICATION.

Irtin G. Friest

7. A PRECISION METHOD FOR FRODUCING ART IFICIAL DAYLIGHT*.

Irmin G. Priest
Rep. Proc. Fourth Ann Meet. Soc. Cotton Products Analysts, June 21,1913, p. 6 .

Rep. Froc. Fifth Ann. Meet. Soc. Cotton Products Analysts, May 16, 1914, p. 22.

Rep. Proc. Sixth Ann. Conv., Soc. Cotton Products Analysts, May 14-15, 1915, p.67.

Trans. Am. Ceramic Soc., 17, 1915.

Fhy.Rev. (2), 6, p.64; July, 1915; and 9 , 0. 341 ; April, 1917; and 10, p. 208; August, 1917 .

Trans. Ill. Ing. Soc., 13, p. 38; FCb. 1918.

Fhy. Rev. (2), /11. 502 ; June, 1918. 
$\because$ 
8. THE LAW OF SYMMETRY OF THE VISIBILITY FUNCTION* Irwin G. Priest

9. A ONE-TERM PURE EXPONENTIAL FORMULA FOR THE SPECTRAL DISTRIBUTION OF RADIANT ENERGY FROM A COMPLETE RADIATOR* Irmin G. Priest

10. PHOTO-ETECTRIC SPECTROPHOTOMETRY BY THE NULI METHOD* K. S. Gibson

11. A NEW FORMULA FOR THE SPECTRAL DISTRIBUTION OF ENERGY FROM A COMPLET RADIATOR* Irmin G. Priest

12- REPORTS ON MILITARY INVESTIGATIONS, 16. AMERICAN PHYSICAL SOCIETY, WASHINGTON, APRIL, 1918.

12. THE SPECTRAL COMPOSITION AND COLOR OF CERTAIN HIGH INTENSITY

SEARCHLIGHT ARCS*

Irmin G. Priest, W. F. Meggers, H. J. MoNicholas, K. S. Gibson, and E.P.T.Tyndall, in cooperation With the sgarchlight Investigation Section, Corps of Engineers, U. S. A.

13. OPTICAL AND PHOTOGRAPHIC METHOSS FOR THE DETECTION OF INVISIBLE WRIT ING*

Irwin G. Priest and E.P.T.

Tyndall

14. REPORT ON THE APPLICABILITY OF ULTRAVIOLET RAYS TO SIGNALING* Irmin G. Priest and K. S. Gibson

15. THE SP ICTRAL TRANSMISSION OF FILTERS USED TO DETECT CAMOUFLAGE OR IMPROVE VISIBILITY*

K. S. Gibson, E.P.T.Tyndall and

H. J. MeNicholas.

16. A METHOD FOR THE COLOR GRADING OF RED FLARES*

Irmin G. Priest
Phy. Rev. (2), II, p. 498; June, 1918.

Jour. Opt. Soc. Am., $\frac{2-3}{1}$, p. 18; Jan.-March, $19 \overline{19 .}$

Jour. Opt. Soc. Am., 2-3, p. 23 ; Jan.-March, $19 \overline{19}$.

Phy. Rev. (2), 13, p. 314; Apr., 1919; and 14, p.191; Aug., 1919.

Phy. Rev. (2), 14, Aug.and Sept., 1919 (pages as indicated.

p. 184

p. 188 p. 188

p. 261 

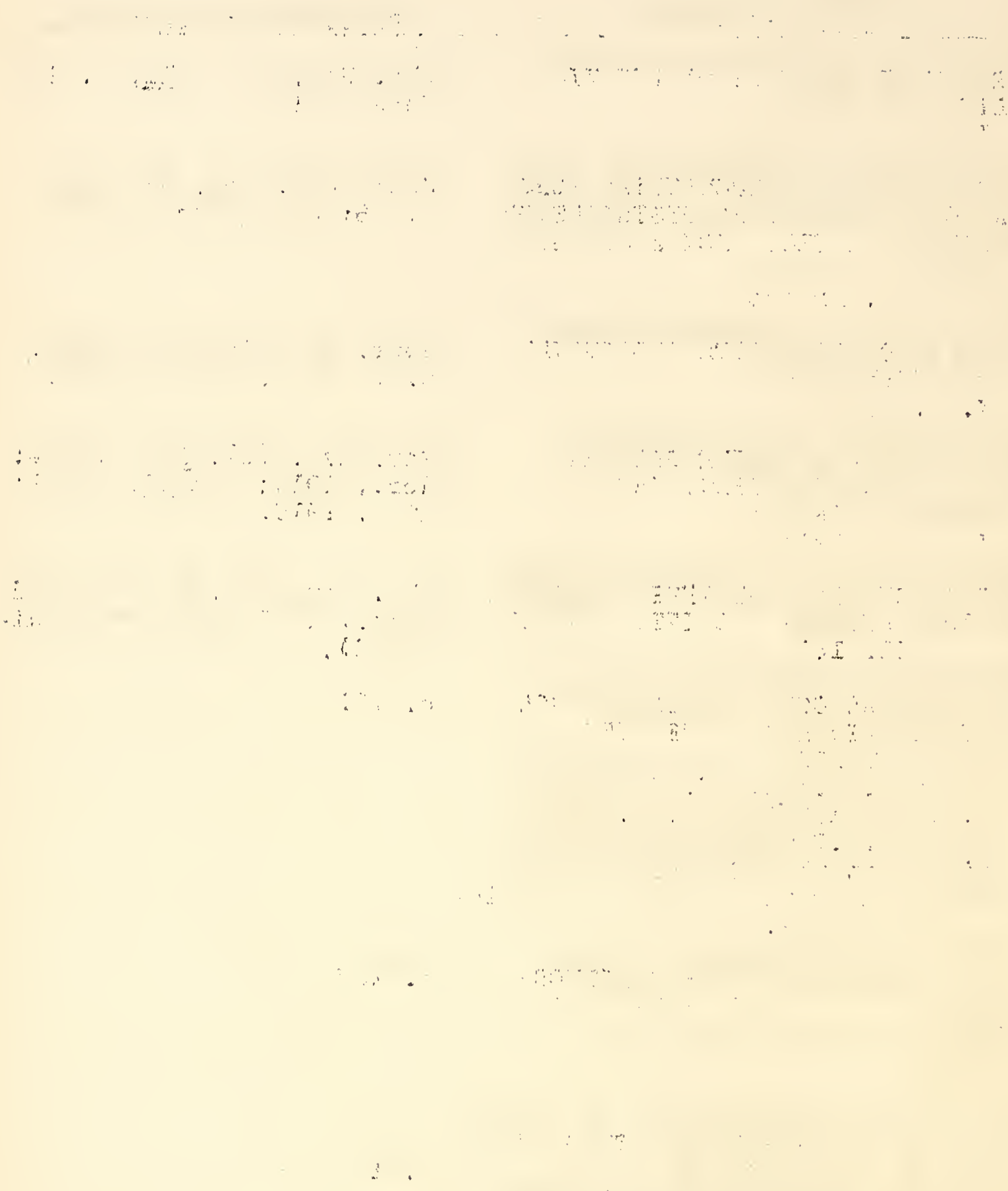
Publication Roferonce

17. THE COLOR OF SOYA BEAN OIL AS COM-

The Cotton 011 Press, Jan., PARED WITH THAT OF COTTON SEID OIL. 1920. Irwin G. Priest

18. REPORT OF THE COLORIMETRY COMMITTEE OF THE OPTICAL SOUIETY OF AMERICA, 1919.

Irwin G. Priest, Chairman.

19. REPORT ON INTESTIGATIONS OF THE COLOR AND SPECTRAL TRANSMISSIVITY OF VEGETABLE OILS*. Irvin G. Priest

20. INFRA-RED ABSORPTION SPECTRA OF VEGETARLE OILS. X. S. Gibson

21. PRELIMINARY NOTE ON THE RELATIONS BETWEEN THE QUALITY OF COLOR AND THE SFECTRAL DISTRIBUTION OF LIGHT IN THE ST IMULUS.

Irmin G. Priest

22. NOTE ON THE RELATION: BETWEEN THE IREQUENCIES OF COMPLEMENTARY HUES. Irwin G. Priest.

23. A NEW STUDY OF THE LEUCOSCOFE AND ITS APPLICATION TO PYROMETRY. Irmin G. Priest

24. REFORT ON CALIBRATION OF SIXTEEN LOVIBOND RED GLASSES.

Irvin G. Priest

25. A METHOD OF OBTAINING RADIANT ENERGY HAVING THE VISIBLE SPECTRAL DISTRIBUTION OF A COMPIETE RADIATOR AT VERY HIGH TEMPERATURES. Irwin G. Priest

26. THE OPTICAI BASIS OF BITTINGER'S CAMOUFLAGE FAINTINGS*.

Irwin G. Friest and M. K. Frehafer.

(Not published; copy may be borrowea from Bureau of Standards' Library. Cf. Jour.Opt.Soc.Am., $\Perp$, p.186; May, 1920.)

The Cotton Oil Press, JuI , 1920.

The cotton $0 i l$ Fress, Seot., 1930 :

Jour. Opt. Soc. Am., 4, p. 389; Sept., 1920.

Jour. Opt. Soc. Am., 龷, p. 403; sept., 1920; and $\underline{5}, p$. 513; Nov., 1921.

Jour. Opt. Soc. Am., $\underline{4}, p$. 448; Nov., 1920.

The Cotton Oil Fress, Jan., 1921.

Jour. Opt. Soc. Am., 占, p. 178; March, 1921.

Jour. Wash. Acad, Sci., p. 238, May 19, 1921. (Cf.' Jour. Op.Soc.Am., 4, pp. 390395; Sept., 1920 . 

27. A DIRECT READING SPECTROFHOTOMETER FOR MEASURING THE TRANSMISSIVITY OF LIQUIDS*.

Irmin G. Priest

28. MEASUR IMENT OF THE COLOR TEMPERATURE OF THE MORY EFFICIENT ARTIFICIAL LIGHT SOURCES BY THE METHOD OF ROTATORY DISPERSION. Irwin G. Priest

29. REPORT OF THE COLORIMETRY COMMITTEE OF THE OPTICAL SOCIETY OF AMERICA, 1920-2I**.

30. *FIGMENTS OF THE MENDELIAN COLOR TYPES IN MAIZE: ISOQUERCITRIN FROM BROWN-HUSKED MAIZE.

Charles E. Sando add H.H.Bartlett

31. THE EFFECT OF VARIOUS CONDITIONS UPON THE DETERMINATION OF THE NORMAL STIAULUS OF GRAY*.

Irwin G. Priest and Casper I. Cottrell

32. PREL IMINARY DATA ON THE COLOR OF DAYLIGHT AT WASHINGTON*. Irmin G. Priest

33. AFPARATUS FOR THE DETERMINATION OF HUE SENSIBILITY (TAVE LENGTH DIFFERENCES PERCEFTIBLE BY DIFFERENCE IN HUE) AND THE VISIBILITY OF RADIANT ENERGY*.

Irwin G. Priest

34. THE EFFECT OF SOME SUBST ITUTES FOR TIN OXIDE ON THE OPACITY OF WHITE ENAMELS FOR SHEET STEEL. R.R.Danielson and M.K.Frehafer

35. SPECTROPHOTOMETRY

K. S. Gibson
Phy. Rev. (z), 18, p. 127; Au.g., 1921.

Jour. Oot. Soc. Am. and Rev. Sci.Inst., 6, p. 27; Jan., 1922 .

Jour. Opt.Soc.Am.and Rev.Sci. Inst., 6, o. 527; Aug., 1922. (Copies may be obtained from Frof.F.K.RIchtmyer, Cornell Univ., Ithaca, N.Y., at $50 \not$ each.)

Jour. Biol. Chem., 54, p. 629; Nov., 1922.

Jour. Opt. Soc. Am. and Rev. Sci. Inst., 1, p. 73; Jan., 1923.

Jour. Opt. Soc. Am and Rev. Sci. Inst., 7, p. 78; Jan., 1923.

Jour. Opt. Soc. Am. and Rev. Sci. Inst., 7, p. 99; Jan., 1923.

Jour. Am. Ceramic Soc., $\underline{6}$, p. 634; May, 1923.

Dict. of Applied Fhysics, 4 , p. $737 ; 1923$. 

36. DIRECT-READING PHOTO-EIECTRIC MEASUREMENT OF SPECTRAI TRANSMISSION

$$
\text { K. S. Gibson }
$$

37. THE COLORIMETRY AND PHOTOMETRY OF DAYLIGET AND INCANDESCENT ILLUMTNANTS BY THE METHOD OF ROTATORY DISPERSION Irwin G. Priest

38. *THE QUANTITATIVE DETERMINATION OF CAROTIN BY MEANS OF THE SPECTROPHOTOMETER AND THE COLORIMETER

F. M. Schertz

39. APPARATUS FOR THE DETERMINATION OF COIOR IN TERMS OF DOMINANT WAVE LENGTH, PURITY, AND BRIGHTNESS

\section{Irwin G. Priest}

40. A COMPARISON OF EXPERIMENTAL VALUES OF DOMINANT WAVE LENGTH AND PURITY WITH THEIR VALUES COMPUTED FROM THE SPECTRAL DISTRIBUTION OF THE STIMULUS* Irwin G. Priest, K.S.Gibson, and A.E.O.MunseII

41. SOME TESTS OF THE PRECISION AND RELIABILITY OF MEASUREMENTS OF SPECTRAL TRANSMISSION BY THE KOENIG-MARTENS SPECTROPHOTOMETER

Irwin G.Priest, H.J.McNicholas, and $M$. Katherine Frehafer

42. THE VISIBILITY OF RADIANT ENERGY K.S.Gibson and I.P.T.Tyndall

43. THE RELATIVE VISIBILITY FUNCTION K. S. Gibson

44. SPECTRAL CHARACTERISTICS OF TEST SOLUT IONS USED IN HETEROCHROMATIC PHOTOMETRY

K. S. Gibson
Jour. Opt. Soc. Am. and Rev. Sci. Inst., 7, p. 693; Sept. 1923.

Jour. Opt.Soc. Am. and Rev.Sc1. Inst. , ?, p.1175; Dec ., 1923;

(Trans.I11.Eng.Soc.,18, 0.861; Nov., 1923. Abstract.)

Jour. Agr. Res., 26, p.383; Dec., 1923.

Jour. Opt. Soc, Am, and Rev,

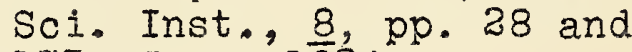
173; Jan., $1 \overline{9} 24$.

Jour. Opt. Soc. Am, and Rev. Sci. Inst., 8, p. 28; Jan., 1924.

Jour. Opt. Soc. Am. and Rev. Sci. Inst., 8, pp. 30 and 201 ; Jan., 1924.
Trans.III. Eng. Soc, 19, 0.176; Feb., 1924.

Proc. of the Int. Comm. on I11., 6th Meeting;July, 1924.

Jour. Opt. Soc. Am. and Rev. Sci. Inst., 歽, p. 113; Aug., 1924. 


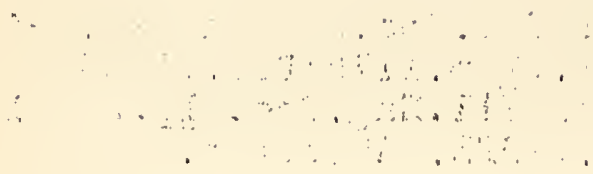

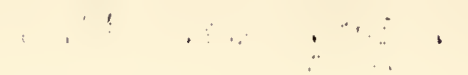

$\begin{array}{llll}\cdots & \cdots & \cdots \\ \vdots & \ddots & \ddots & \ddots \\ \ddots & \ddots & \ddots\end{array}$

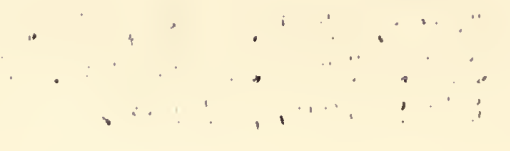

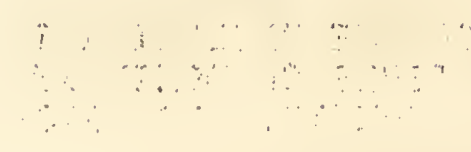

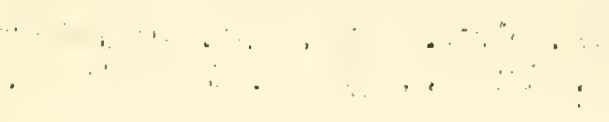


45. *SPECTROPHOTCMTTRTC ANALYSIS APFIIED TO OHROLOIROPE $10 \mathrm{OH}$. iN.D. Appel ara W.R.Brcie

46. *THE ELIMINATION OF TAPTAELES IN THE DIELTG METHCD OF NESTING DYFS.

William D. Appel

47. *OPTICALIY ACTIVE DYES II. ADSORJTION, ABSORPTION SPECTRA AIID POTATION.

Wallace R. Brode with Roger Adams

48. VISIBIIITY OF RADIANT ENERGY EQUATION.

E.P.T.TyndalI and $K$. S. Gibson

49. THE COMPUTATION OF COLORIMETRIC PURTMY.

Irwin G.Priest, I.3.Tuckerman, Herbert $\mathrm{E} . I v e s$, and F.K.Harris

50. SPECTROPHOTOMETRY, REPORT OF THE OPTICAL SOCIETY OF AMERICA PROGRESS CONIITTEE FOR 1922-23**. K.S.Gibson, Chairman.

51. *THE QUANTITATIVE DETERMINATION OF XANTHOPHYLI BY MEANS OF THE SPECTROPHOTOMETER AND THE COIORIMETER.

F. M. Schertz

52. TUE SPECIFICATION OF COIOR IN TERMS OF DCMINANT WAVE LENGTH, PURITY, AND BRIGHTNESS*.

Irmin G.Priest, K.S.Gibson, and A.E.O.MunseII

53. * SOME PHYSICAI AND CHEMICAI PROPERTIES OF CAROTIN AND THE PREPARATION OF THE PURE PIGMENT. F. M. Schertz
Ind, and Eng. Chem., 16, p. '797\%; Aug., 1924.

Am. Dyestufi Reporter, 13, p. 507; Aug., 1924.

Jour. Am. Chem. Soc., 46 , p. 2032; sept., 1924.

Jour. Opt. Soc. Am. and Rev. Sci. Inst., 9, p. 403; Dot., 1924 .

Jour. Opt. Soc. Am. and Rev. Soi. Inst., 9, p. 503; Nov., 1924.

Jour. Opt. Soc. Am, and Rev. Sci. Inst., 10, p. 169; Feb., 1925.

Jour. Agr. Res., 30, p. 253; Feb., 1925 .

Jour. Opt. Soc. Am. and Rev. Sci. Inst., 10, p. 291, Harch, 1925.

Jour. Agr. Res., 30, 0.469; March, 1925. 

54. * SOME FHYSICAL AND CHEMICAI PROPERTIES OF XANTHOPHYLL AND THE FREPARATION OF THE FURE FIGMENT

F. M. Schertz

55. MEASUREMENTS OF ILIUNINATION AND COLOR TEMPERATURE AT TASHINGTON DURING THE SOLAR ECLIFSE, JANUARY 24, 1925*

Irw in G.Friest, K.S.Gibson, and $F \cdot K$.Harris

56. DETERMINATION OF THE TIME OF A SOLAR ECLIPSE FROM MEASUREMENTS OF REIATIVE ILLUMINATION*.

Irw in G.Friest, K.S.Gibson, and $F . K . H a r r i s$.

57. SOME TESTS ON THE ACCURACY OF MEASUREMENT TITH THE ROTATORY DISPERSION COLORIMETRIC PHOTOMETER.

K. S. Gibson

58. GRAY SKIES AND WHITE SNOW* Irmin G. Priest

59. COLORS AND FORMS OF TRAFFIC SIGNALS (CODE PROPOSED BY SECTIONAL COMMITTEE OF THE AMERICAN ENGINEERING STANDARDS COMNITTEE) **.

60. *TRAFFIC SIGNALS. Morton G. Lloyd

61. REPORT OF THE OFTICAL SOCIETY OF AMERICA PROGRESS COMMITTEE ON RADIONETRY AND FHOTOMETRY FOR 1923$24 * *$

62. SFECTRAI CENTROID REIATIONS FOR ARTIFICIAI DAYLIGHT FILTERS

K. S. Gibson
Jour. Agr. Res., 30, p. 575; March, 1925.

Fhy. Rev. (2), 25, p. 901; June, 1925.

Fhy. Rev. (2), 25, p. 902; June, 1925.

Jour. Opt. Soc. Am, and Rev. Sci. Inst., 11, p. 75; July, 1925.

Jour. Wash. Acad. Sci., I5, p. 306; July 19, 1925; Jour. Opt.Soc.Am.and Rev.Sc1.Inst., 1?, p. 133; Aug., 1925.

Fublic Roads, U.S.Dept.Agr., 6, p. 134; Aug., 1325.

Proc.Int.Assoc.Nunic. Ilec., p. 154; 1925.

Jour. Opt. Soc. Am. and Rev. Sci. Inst., 11, p. 357; Oct., 1925.

Jour. Opt. Soc.Am. and Rev.Sci. Inst., 11, p. 473; Nov.,1925. 

63. *THE EFFECT OF SOIVENTS OIN THE ABSORPTION SPECIRUU CF A SIVPIE AZO DYE.

Wallace R. Erode

64. STANDARD ARTIFIOTAI SUINIGHT FOR CUIORTMETRTO PURPOSES* Irrin G. Priest

65. A SPECTROPHOTOMETRTC ANALYSIS OF THE IOTIBDHD COLOR SYSTHIF* K.S.Gibson and $\bar{F}$. K. Harris

66. THE UITT OF PHOTOGRAPHIC INTENSITY, REPORT OF I'HE OPPICIL SOCTETY OF AUERICA COMIIIEI**

67. EEPORT OF THE OPTICAI SCCIETY OF ANERICA OOMITTET ON COLOR LEEINOLOGY QUESTIOINAIRE**

68. THE COMPUTATION OF COLORIMETF.IC FURITI, II.

Irvin G. Friest

69. THE CONPUTATION OF COLORIMETRIC FURITY

Deane B. Judd

70. THE ERODUCTION CF RADIANT ENERGY OF UNIFORM INT YISITY OVER

THE VISIBLE SPECTRUM*

K. S. Gibson

71. AN EXPERIMENT BEARING ON THE ADOPTION OF A STANDARD NEUTRAL STIMULUS IN COIORIMETRY; THE CEICE AS EETHEN "SUN" AIND "EQUAL ENTRGT" * Irwin G. Friest

72. THE NINIMUN FERCEPTIBLE COLORIMETRIC PURITY AS A FUNCTION OF DOMINANT WAVE IJENGTH WITH SUNLIGHT AS NEUTRAL STANDARD*. Irwin G.Friest and F.G.Brickredde
Jour. Phys. Chem., 30, p.56; Jan., 1926.

Jour. Opt. Soc. Am. and Rev. Soi. Inst., 12, p. 479; May, 1026.

Jour. Opt. Soc. Am., and Rev. Soi, Inst., 12, p. 481; May, 1926.

Jour. Opt. Soc. An. and Rev. Sci. Inst., 12, p. 567; June, 1926.

Jour. Opt. Soc. Am. and Rev. Sci. Inst., I3, p. 43 ; Ju$1 \mathrm{y}, 1926$.

Jour. Opt. Soc. Am. and Rev. Sci. Inst., 13, po. 123-132; Aug., 1926 .

Jour. Opt. Soc. Am. and Rev. Soi. Inst., 13, pp. 133-155; Aug., 1026 .

Jour. Opt. Soc. Am. and Rev. Set. Inst., 1.3, p. 305; Sept.: I026.

Jour, Opt. Soc. Am. and nev. Sct. Inst., 13, p. 305; Sept., 1925.

Jour. Opt. Soc. Am. and Rev. Sci. Trst., 13, pp. 306-307; sevt., 1926. 
C. remen 
73. BLUE SKY AND WHITE SNOW* Irwin G. Priest

74. *THE COLOR TEMPERATURE OF GASFILLED LAMPS AS A FUNCTION OF TIME IN SERVICE*

H. E. Howe

75. SPECTRAL FILTERS

$$
\text { K. S. Gibson }
$$

76. *THE ABSORPTION SPECTRA OF BENZENEAZOBENZENE Wallace R. Brode

77. *THE DISSOCIATION OF POTASSIUM IODIDE AIID THE ABSORPTION SFECTRA OF IODINE AND POTASSIUM IODIDE

Wallace R. Brode
Jour. Opt. Soc. Am. and Rev. Sci. Inst., 13, p. 308; Sept., 1926.

Jour. Opt. Soc. Am, and Rev. Sci. Inst., 13, p. 304; sept., 1926.

Jour.Opt.Soc.Am.and Rev.Sci. Inst., 13, p. 267; Sept., 1926.

Jour. Am. Chem. Soc., 48, pp. 1984-1988; 1926.

Jour. Am. Chem. Soc., 48, pp. 1877-1882; 1926. 
$\therefore \quad-\cdots$

$\therefore \therefore$

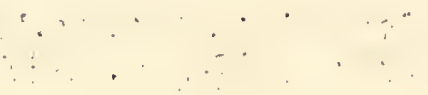

$, \cdots, \quad, \quad+\vdots$ 


\section{B. UEEA U OE S I A D A R D S Colorinetry Section \\ Publications During the Fiscel Yeer 1927 (JuIJ 1, 1926 - June 30, 1927)}

I. Officiel Publicetion by the Goremnent Printing office:

Titze and Author

Date of Payer Price Issue ITo.

IHE IOVIBOND COIOR STSTYT. I. A SPECPRO- FeD. I7, S 547 156 PHOTOIEIPIC ANATYSIS OP THE IOVIBOID

GTHSSES

Y. S. Gibson, T. Y. Tarris, end

Irvin G. Priest

II. Pajers Bmenating from the Colorimetry Section, Bureeu of

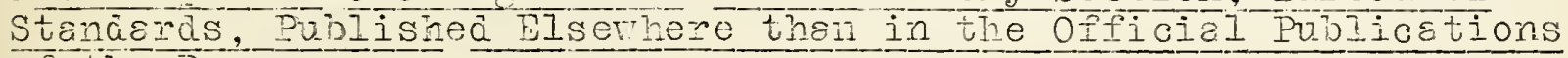
of trie Bureau.

An asterist (*) before the title indicates that the work is only in pert the product of the colorimetry Iaborstory. It usually means trat sore iso vas mede of ejoretus and facilities afforded by the section, or thst the suthor obteined considersble advice and assistance from mabers of the section.

An asterisk ( ${ }^{*}$ ) seter the title indicstes sn abstrat of a jeper presented before sorre scientirio society.

Two asterisis ( ${ }^{2}$ ) after the title incicste c committee report in the orearation of wich sore nembers of the section coopercted. Titie and author publication Reference

67. REPOET JP THY OPTIAA SOUIETY CTI AERTC COMITTE OIT COLOR TOPEITOICGY OUESTIOHIATPE

68. TIE COIDUTATIO" CT COIJRIIETIT PURITY, II Irvin $G$. siesi

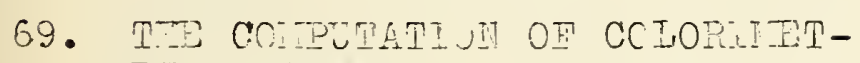
RIC ILEI I

$$
\text { Deane B. Jnad }
$$

70. ITE PPODTCTIOI CT RADIATP ENERGI CT UITIOPI IIVTISIZT OVAR TID VISTBIE, SPECTRTI:*

$$
\text { K. S. Cinson }
$$

Jorn. Oot. Soc. Ara. and Rev.

Soi. Inst., I5, 2. 43; JuIJ, 1926.

Jour. 0ut. Soc. Arn. End Rev. Sci. Inst, 15, p. 123; Aug., 1926.

Jour. Opt. Soc. At. End F.ët. Soi. Inst., I3, 2. 133; IT. 1926.

Jour. Oat. Soc. Am. and Per. Sci. Inst., 13, э. 305; Sept., 1926. 

71. AI ERPARITEYT BDAPITYG OI TIE

ADCPTIOI OT A STAIDARD IRUTRAI SIIIUIJS IIT COIORIIETRY; THE CHOICE AS BETTIDI "SUIT" AITD

"DOETAT TIEPGY"

Irwin $G$. Priest

72. TIE ITITIUE PURCLPTBED COIORIIETRIC PURIPY AS A TUUTUIOTT OH DO-ILAIT IAVE JEIGTH TITH SUITIGHT AS IPUTREI. STAIDARD* Irwin G. Priest and

F. G. Briclrvedde

73. BLUE SEY ATD RTITE SPON

Irvin $G$. Priest

74. TEE COEOE TAITPRATUPE OD GASRITIED ILIPS AS A RUISTION OP TIIS II SERVICE*

$$
\text { H. 巴. Howe }
$$

75. SDECTRED FITERS

I. S. Gibson

76. * THE ABSORPIIOT SFECTPA OTI JDIZETIAAOBRTZEIE

rallece R. Brode

77. * THE DISSOCIKIIOT CF POTLSSIUII IODIDE AID RTE ABSORPTIOT: SPECTR: OE IODIIE ITD POT LSSIUII IODID?

Vallace P. Brode

78. * OPTICAIIY LCIIVD BYES. III. PHISIC $I_{i}$ PRO PERTIES, DIEITG

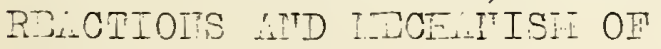
DYEIIG

Wallace R. Brode with

Poger idams

79. * OPTICAIIY ACTIVE DYES. IV. ASYIIPTRIC DIPS TPOO ITAAAIIIOINIDEIIC ACID

Tallace P. Brode with

Porer fidems
Jour. Opt. Scc. Am. and Rev. Sci. Inst. 13, D. 306; Sept. , 1926.

Jour. Opt. Soc. Am. aid Rev. Sci. Inst., 13, po 306 ; Sept., 1926 。

Jour. Opt. Soc . Nm. and Rev. Sci. Inst. 13, p. 308; sept., 1926.

Jour. Opt. Soc. Am and Rev. Sci. Inst. 13, D. 304;

Sept。, 1926.

Jovr. Opt. Soc. Ar. and Rev. Sci. Inst., 13, ‥ 267; Sert., 1926.

Jour. Im. Cinem. Soc., 48, p. 1984; JuIJ, 1926.

Jour. im. Chen. Soc •, 48 , p. 1877; July, 1926 。

Jour. im. Chem. Soc., 48, D. 2193; ivgust, 1926.-

Joux. in. Chem. Soc , 48, ก. 2202; Auzust, 1926. 

80. * RTPRODUCIBIE IIOUID FIITEES TOR TEE PRODUCTIOI OF "WEITE I.ICHTI"

‥ Davis ana K. S. Gibson

81. A PROPOSDD IPMTCD TOR THE IEASUPII DIT OP THE RELATIVE VISIBIIITY FURCTIOI* *

K. S. Gibson

82. APPARATUS TOR TFE DETPRIIIATIOR Jour. Opt. SOc. Am. and Pev. OF THE VISIBILIMY OI ENPRGY AITD Sci. Inst•, 14, p. 136; Teb•, THE NUITDAENTAI SCAIES OF VISUAI 1927. PSYCHOPTYSICS*

Irwin G. Priest and K. S.

Gibson

83. SEISIBIIITY TO TAVEIDNGTE DIFTRRDIPE AS A TUI:TIOI OT PURITY* D. P. T. Tyทล่EII

84. SETSIBIITTY TO TAVELRIGTH DITITREITE AIP TIE PRTCISION OP IIEASURETIITT OT DOIITTSITT WAVEIEHGTH TOP YELIOY COLORS OP HIGH SATUPATIOI?*

Irwin G. Priest and D. B. Judd

85. IT EXPEPIIETT ON COLOR DISCRIIIINATON UNDER COITORPIACE CONDITIOTS*

Irvin G. Priest

86. OT THE USE OI TUE ITTEGR TIITG SPIERE IT RETLECTOIETRY*

H. J. Maricholes

87. *PEPRODUCIBIE IIGUID TIITERS FOP THE DETERIITITIOI OT THE COIOR TEIPER PURES OT INCAITDESCENT ISITP*

R. Davis and K. S. Gibson

88. PUPTTY IND SATUPARIOT; $A$ SATURITIOI SC'LE IOP YEIIOT *

Desne B. Juda

89. THE DIPIRIC PEIATIOIT BETTEET DOIIIISITT WIVE LEITGTH ITD PUPITY**

Deane 3. Juda
Jour. Opt. Soc. Am. end Rev. Sci. Inst., 14, p. 135; Peb. 1927.

Jour. 0pt. Soc. An. and Rev. Sci. Inst., 14, p. 135; Neb. 1927.

Jour. Opt. Soc. Am. End Rev. Sci. Inst., 14, p. 137; Feb. 1927.

Jour. O t. Soc. Arn. and Rev. Sci. Inst., 14, p. 137; Ieb. 1927.

Jour. Opt. Soc. im. and Rev. sci. Inst., 14, p. 138; reb., 1927.

Jour. Opt. Soc: Lm. and Rev. Sci. Inst., 14, p. 142; Ieb., 1927 .

Phys: Rev. (2), 29, p. 916; June, 1927.

Jour. Opt.'Soc. im. and Rev. Sei. Inst., 14, p. 470 ; June, 1927.

Jour. Opt. Soc: $\mathrm{m}$. and Rev. Sci. Inst., 14, p. 475; June, 1927. 


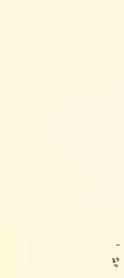


$B U R E A U$ O F S TANDAF $D$ Colorimetry Section

Publications During the Fiscal Year 1928 (July 1, 1927 - June 30, 1928)

I. Official Publications by the Government Printing office.

Twc asterisks $(* *)$ before the title indicates that the paper emanates from some section of the Bureau other than the Colorimetry section. but has a bearing on colorimetry or close relation to it. Eorever numerous papers which mi ht bo so classed (on spectroraclometry, pinctometry. etc. I tre no sstad here. For complete list, consult B. S. Circular No. 24 , and supplements to it.

Title and Author

Date of Paper Price Issue No.

** COLOR IN THE SUGAR INDUSTRY H. H. Peters and F. P. Phelps

March 12, T 33820 c 1927

** TRANSIIISSIVE PROPIRTIES OF EYEPROTECTIVE GIASSES AIND OTHER SUBSTANCES

W. W. Coblentz and R. Stair

II. Papers Emanating fror the Colorimetry Section, Bureau of Standards, Published Elsewhere than in the Official Publications of the Bureau.

An asterisk $(*)$ before the title indicates that the work is enly in part the product of the Colorimetry Iaboratory. It usually means that some use was made of apparatus and facilities afforded by the section, or that the author obtained considerable advice and assistance from members of the section.

An asterisk $(*)$ after the title indi cates an abstract of a paper presented beiore some scientific society.

Title and author

90. CORRECTION OF A PRIVALEIT ERROR IIN REGARD TO THE DATA OIN PHOTOMETRIC STISIBILITY AS A FUNC'TION OF WAVE IENGTH AT LOW BRIGHTNESS Irwin G. Priest

91. NOTE ON THE RELATIVE COMFORT IN READING BY ARTIFICIAL DHYLIGHT AND UNMOIIFI D GAS-FILIED TUNGSTHN LAIIPS Irwin G. Priest
Publication Reference

Jour. Opt. Soc. Am. and Rev. Sci. Inst., I5, p. 82; Aug., 1927.

Jour. Opt. Soc. Am. and Rev. Sci. Inst., 15, p. 131, Sept., 1927. 

92. *A METHOD FOR MEASURING THE COIOR

OF' TPYYTTTES

Wiliam D. AppeI

93. A STUDY OE I I2 I.OVTBOND RFD GLASSES WITH IFSP TOT TO THE PEIIABILITY OF THE IR NTHAA GEADS

Derre i3. Tuli. aris

Geialuilue ne, velser

34. SATURATIOI OF COURO DETERMINED FROM TI- TISUA TISPOINE FUNCTIONS* Derise $B$, suad

95. SENSIBITITY TO $C O T O R$ CILNGE DETERMIN-

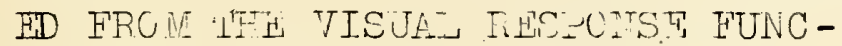
TIONE: WTISTON 'LO COMPLETE AND PARTIA TICAROMLSY*

Dezie E. Tudद

96. STANDARDIZING THE RED AND YELIOW LOVIBOITI RIASSES*

Irwir $G$. iniest and

K. S. Gjison

37. PREIIIINARY DATA ON THE LEAST PERCEPTIIT JIFASENCE IN DOMINANT WAVF I DV THE METHOD OF RIGHT AND WRCNG ANSWLPS* Irvin G. Pritst

98. * COLOP. TUIE LRATURE CLASSIFICATION OF NATURAI AND ARTIFICIAL ILLUMINANTS

Norman Niacbeth

99. TESTS OF COLOR SENSE OF A.O.C.S. NEMBERS HIND DATA ON SENSIBIIITY TO CHANGE IN IOVIBOND RED

Irwin G. Priest

100. *FIITERS FOR THE REPRODUCTION OF SUNIIGHT HID THE DETERIINATION OF COLOR TEMPERETURE*

Raymend Davis and

K. S. Gibs on
Am. Dyestuff Reportar, Jan. 23, 1928, p. 49 .

Oil and Fat Industries, 5, p. 16; Jan., 1928 .
Jour. Opt. Sec. Am. and Rev. Sci. Inst., I6, p. 115; February, $19 \overline{28}$.

Jour. Opt. Soc. Am. and Rev. Sci. Inst., 16, p. 115; Feb., 1928 .

Jour. Opt. Soc. Am. and Rev. Sci. Inst., 16, p. 116; Feb., 1928 .

Jour. Opt. Soc. Am. and Rev. Sci. Inst., I6, $\mathrm{p}$. $117 ; \mathrm{Feb} ., 1928$.

Trans. Ill. Eng. Soc., 23, p. 302; Mar., 1928.

Oil and Fat Industries, 5, p. 63; Mar., 1928.

Jour. Opt. Soc. im. and Rev. Sci. Inst., 16, p. 332; Nay, 1928.

101. EQUIPMENT FOR ROUTINE SPECTRAL TRAINS- JOur. Opt. SOc. Am. and MISSION AND RPILECTION MEASUREVENTS* ReV. SCi. Inst., 16, p. H. J. McNicholas 333; May, 1928. 
102. *AFTIFICIAL SUNIIGHT FOR PHOTOGRAPHIC SENSITCNETRY Raymond Datis and K. S. Gibson

103. STLIDDARDIZATION Oঙ IOVIBOID GILASSIS (MONTHLY RETPORTS FROM CALCRIMETEY SECTICN TO PEESIDENT OF AMERICAN OIL CHEMISTS' SECIETY)
Trans. Soc. Motion

Picture Engineers, 1E, p. $225 ; 1928$.

Oil and Fat Industries, 4, p. $433 ;$ Dec., 1827 ;

ㅎ, p. $27 ;$ January;

p. 58; Ferruary;

r. 9R; March;

r. 114; Axril;

p. 152; May;

p. 184; June (there are rany typogra.chical errcrs in this rep(rot);

p. ЋЕЗ; TUIy;

p. 247; A.uglist;

c. 278; September, 1928. 



\section{B U R E A U O F S TAN D A R D S Colorimetry Section}

Publications During the Fiscal Year 1929

( July 1, 1928 - June 30, 1929)

An asterisk (*) before the title indiicates that the paper is only in part the product of the Colorimetry Section.

Two asterisks $(* *)$ before the title indicate that the paper emanates from some section of the Bureau other than the Colorimetry Section, but that some use was made of apparatus and facilities afforded by the latter section or that the author obtained considerable advice or assistance from its members.

Numerous papers which have a bearing on Colorimetry or close relation to it, e.g., on spectroradiometry, photometry, etc., are not listed here. For complete list, consult B. S. Circular No. 24, and supplements to it.

I. Official Publications by the Government Printing office.

These papers may be obtained fror the Superintendent of Documents, Government Printing Office, Washington, D. C., at the prices noted.

Date of Paper

Title and suthor

Issue

No.

Price

ABSOLUTE WEIHODS IN RIFLECTORETRY

H. J. McIJicholas

July,

1928

RP3

$10 \varnothing$

** TINTIIG STRETGTH OF PIGMEITS

H. D. Bruce

August,

1928

RP7

$10 \notin$

EQUIPIAEIT FOR ROUTINE SPECIRAL

TRAISSMISSION AIND REPLECTION

MEASUR HITINTS

H. J. McNicholas

November,

1928

RP30

$20 \notin$

EFFECT OF TEMPERATURI CHAIJGE ON THE COLOR OE. RED AND YELIOW LOVIBOND GLASSIS

Deane B. Judd

lio vember,

1928

RP3I

$5 \notin$

USE OF THE UNDER-WATEP SPARK WITH

THE HILGER SECTOR PHOTOMETIR IN

ULTRA-VIOIET SP ECTROPHOTOITETRY

H. J. MCNichol as

December,

1928

RP33

$5 \notin$

LEAST RETINAL ILLUMINATIOIN BY

SP ACTRAI LIGHT REQUIRED TO EVOKE

THE "BLUE ARCS OF TPIE RETINA"

Deane B. Judd

February,

1929

RP43

$5 \varnothing$ 

** THE SPECTRAL ABSORPTIOI OF CERTAIN MONOAZO DYES

Wallace R. Brode

March, 1929

$\mathrm{RP} 47$

$15 \not$

CALIBRATION OF SIXIY-FIVE 35-YEL-

LOW LOVIBOND GLASSIS

Irwin G. Priest, Deane B. Judd,

K. S. Gibson, and Geraldine K. April,

Walker

Apri1
1929

RP58

$10 \varnothing$

II. Papers Published Elsewhere than in the Official Publications of the Bureau.

in asterisk (*) after the title indicates an abstract of a paper presented before some scientific society.

Two asterisks (**) after the title indicate a committee report in the preparation of which some members of the section cooperated.

Title and author

104. ANERICAN STINDERD COLORS FOR

TRAFFIC SIGNAIS** (smitted

from previous list) American

Standards Association

105. THE UNIT OF DHOTOGRAPHIC IN-

TINSITY** Report of the

O.S.A. Committee on the Unit

of Photographic Intensity,

I. A. Jones, Chairman

106. *ARTIFICIAL SUNLIGHT FOR PHOTOGRAPHIC SHNSITONETRY

Raymond Davis and

K. S. Gibson

107. SPTCTRAL FILTERS

K. S. Gibson

108.**AN INTERLABORATORY CONPARISON

OF COLORED PHOTOIETRIC FILTTRS

i. C. Crittenden and

A. H. Taylor

109. RESOLUTIONS JPALIING WITH THE PHO TOGRAPH IC UNIT OF INTI ENSITYY PRESTNTED AT TTEE INTERNAT IO NAL CONGRESS OF PHOTOGREPHY* **

Report of the O.S.H. Crmmittee on Standards of Photographic

Intensity, I.A. Jones, Chairman
Publication Reference

A. S. A., 29 West Thirty-ninth street, New York, N. Y., Nov. 15, 1927; 25

Proc. 7 th International Congress of Photography, Lond on, July, 1928, pp. 152-161.

Proc. 7th International Congress of Photography, London, Ju1y, 1928, pp. 161-173.

Int. Crit. Tab., $\underline{5}$, pp. 271274; 1929 .

Trans. Illum. Eng. Soc., 24, pp. 153-207; Feb., 1929.

J. Opt, Soc. Am, and Rev, Sci. Inst., 18, pp. 162-163; March, 1929 . 



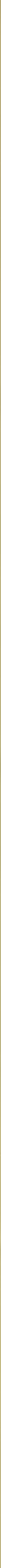


